\title{
IMPLEMENTASI PAJAK PERTAMBAHAN NILAI DI INDONESIA: SUATU STUDI PERBANDINGAN DI NEGARA-NEGARA ASEAN-9
}

\author{
Setiadi Alim Lim \\ Program Studi Akuntansi Politeknik Ubaya \\ Jalan Ngagel Jaya Selatan 169, Surabaya \\ setiadi.alim@gmail.com
}

\begin{abstract}
Indonesia was the first country in Southeast Asia to implement the Value Added Tax on April 1, 1985. This step was then followed by several other countries in Southeast Asia, particularly those who were members of the ASEAN community. However, there are also a number of ASEAN member countries that do not use the Value Added Tax system. In this paper, a comparative study will be carried out on the application of Value Added Tax in Indonesia, compared to other ASEAN member countries, specifically with 8 ASEAN member countries, namely the Philippines, Cambodia, Laos, Malaysia, Myanmar, Singapore, Thailand, and Vietnam which together with Indonesia hereinafter referred to as ASEAN-9. Comparisons are only made among the 9 ASEAN member countries, and not the whole 11 ASEAN member countries, due to difficulties in gathering data from the other 2 ASEAN member countries. Overall implementation of Value Added Tax, or similar taxes in ASEAN-9 countries is good, and has many similarities in principle. This of course will provide many conveniences if it is desired to integrate the Value Added Tax system, or similar taxes into only one tax system that is uniformly applicable in ASEAN countries. From the results of comparative studies show that the implementation of Value Added Tax in Indonesia is still the best compared to 8 other ASEAN-9 countries, because it is in accordance with the basic principles of the Value Added Tax system. However, the Value Added Tax system implemented in Indonesia needs to be improved by removing the Value Added Tax collection rules by government treasurers, and certain business entities when making a purchase from a Taxable Entrepreneur.
\end{abstract}

Keywords: Value Added Tax, threshold, tax rate.

\footnotetext{
ABSTRAK

Indonesia merupakan negara pertama di Asia Tenggara yang mengimplementasikan Pajak Pertambahan Nilai pada tanggal 1 April 1985. Langkah Indonesia ini kemudian diikuti oleh beberapa negara lain di Asia Tenggara, khususnya yang tergabung dalam komunitas ASEAN. Namun demikian ada juga beberapa negara
} 
anggota ASEAN yang tidak menggunakan sistem Pajak Pertambahan Nilai. Pada tulisan ini akan dilakukan studi perbandingan mengenai penerapan Pajak Pertambahan Nilai di Indonesia, dibandingkan dengan negara-negara anggota ASEAN lain, khususnya dengan 8 negara anggota ASEAN, yaitu Filipina, Kamboja, Laos, Malaysia, Myanmar, Singapore, Thailand, dan Vietnam yang bersama dengan Indonesia selanjutnya disebut sebagai ASEAN-9. Perbandingan hanya dilakukan di antara 9 negara anggota ASEAN, dan bukan 11 negara keseluruhan anggota ASEAN, karena kesulitan mengumpulkan data dari 2 negara anggota ASEAN lainnya. Secara keseluruhan impelementasi Pajak Pertambahan Nilai, atau pajak sejenisnya di negara-negara ASEAN-9 sudah baik, dan mempunyai banyak kesamaan secara prinsip. Hal ini tentu saja akan memberi banyak kemudahan bila diinginkan untuk mengintegrasikan sistem Pajak Pertambahan Nilai, atau pajak sejenisnya menjadi hanya satu sistem perpajakan yang seragam berlaku di negara-negara ASEAN. Dari hasil studi perbandingan menunjukkan bahwa implementasi Pajak Pertambahan Nilai di Indonesia masih tetap menjadi yang terbaik dibandingkan dengan 8 negara ASEAN-9 lainnya, karena telah sesuai dengan prinsip dasar sistem Pajak Pertambahan Nilai. Namun demikian sistem Pajak Pertambahan Nilai yang diterapkan di Indonesia perlu diperbaiki dengan menghapus aturan pemungutan Pajak Pertambahan Nilai oleh bendaharawan pemerintah, dan badan-badan usaha tertentu saat melakukan pembelian dari Pengusaha Kena Pajak.

Kata kunci: Pajak Pertambahan Nilai, ambang batas, tarif pajak.

\section{PENDAHULUAN}

Pada dasarnya setiap negara di seluruh dunia mendapatkan sebagian besar pendapatannya dari sumber penerimaan pajak. Sedangkan penerimaan dari sumber non pajak biasanya hanya merupakan pendapatan tambahan. Oleh karena itu, fungsi pajak sangat penting dalam memenuhi kebutuhan anggaran pengeluaran dari suatu negara. Apabila pendapatan pajak dari suatu negara mengalami permasalahan, atau tidak dapat mencapai target yang sudah ditentukan, maka secara otomatis negara tersebut juga tidak akan dapat membiayai semua pengeluarannya secara normal. Dalam kondisi demikian, negara tersebut harus mengurangi jumlah pengelurannya dengan menghilangkan, atau menunda pengeluaran yang dianggap belum prioritas. Jika negara tersebut tetap menginginkan anggaran pengeluarannya tidak berubah, maka kekurangan penerimaan dari sumber pajak dapat digantikan dengan sumber penerimaan dari non pajak, atau berusaha memperolehnya dari pinjaman.

Penerimaan dari sumber pajak dapat dikelompokkan atas penerimaan pajak langsung, dan pajak tidak langsung. Setiap negara dapat menetapkan kebijakan sendiri jenis pajak mana yang akan dijadikan tulang punggung untuk penerimaan dari sumber pajak. Pajak tidak langsung yang banyak dikenal adalah pajak konsumsi. Pajak konsumsi dapat dibedakan atas jenis pajak konsumsi yang single stage, dan multi stage. Pajak konsumsi single stage hanya dipungut satu kali saja, 
sedangkan pajak konsumsi multi stage pemungutannya dapat berkali-kali. Di samping itu, pajak konsumsi juga dapat dibedakan atas pajak yang dipungut kumulatif (cumulative tax), atau dipungut atas nilai dari barang, atau jasa yang dikonsumsi secara keseluruhan, dan pajak yang tidak dipungut kumulatif (non cumulative tax), yaitu pajak yang dikenakan hanya terhadap nilai tambah barang, dan jasa yang dikonsumsi.

Pajak tidak langsung yang populer digunakan oleh banyak negara saat ini adalah Pajak Pertambahan Nilai (Value Added Tax). Pajak Pertambahan Nilai ini tergolong pajak konsumsi yang multi stage, non cumulative. Pajak Pertambahan Nilai adalah sistem pemajakan tidak langsung yang diterima secara luas dan lazim di seluruh dunia. Di mana pada akhir tahun 1960-an hanya digunakan kurang dari 10 negara. Saat ini sudah diterapkan di banyak negara. Penyebaran penerapan Pajak Pertambahan Nilai di banyak negara merupakan perkembangan terpenting dalam perpajakan pada setengah abad terakhir (Charlet and Buydens, 2012). Pernyataan senada dari Bird (2005) yang menyatakan bahwa Pajak Pertambahan Nilai pada dekade-dekade akhir ini menjadi pajak tunggal yang paling penting di negara-negara maju dan negara-negara ekonomi transisi.

Data OECD (2019) menunjukkan bahwa kontribusi rata-rata berbagai jenis pajak terhadap penerimaan pajak keseluruhan negara-negara anggota OECD: 23,9\% adalah Pajak Penghasilan Orang Pribadi, 9,3\% adalah Pajak Penghasilan Korporasi, 26\% Kontribusi Jaminan Sosial, 5,8\% Pajak Properti, 20,2\% Pajak Pertambahan Nilai, 12,2\% Pajak Konsumsi lainnya, dan 2,6\% pajak lainnya. Data ini menunjukkan bahwa peranan dari Pajak Pertambahan Nilai terhadap total penerimaan pajak sangat besar. Lebih dari $20 \%$ dari penerimaan pajak berasal dari Pajak Pertambahan Nilai.

Pada tahun 2015 negara-negara Asia Tenggara yang tergabung dalam ASEAN (Association of Southeast Asian Nations) mendeklarasikan Masyarakat Ekonomi ASEAN (ASEAN Economic Community). Tujuan dibentuknya Masyarakat Ekonomi ASEAN adalah untuk mengintegrasikan ekonomi negaranegara anggota ASEAN. Walaupun masih perlu melalui peta jalan yang panjang, namun arah kebijakan yang ditempuh untuk mengintegrasikan ekonomi sudah disepakati dalam suatu blue print.

Dalam usaha melakukan integrasi ekonomi, faktor pajak juga merupakan hal penting yang perlu menjadi perhatian masing-masing negara. Variasi, dan keberagaman pajak yang diterapkan di masing-masing negara bisa menjadi hambatan yang serius dalam proses integrasi ekonomi ASEAN. Salah satu pajak yang harus menjadi perhatian dari masing-masing negara ASEAN adalah pajak konsumsi yang berupa Pajak Pertambahan Nilai, atau pajak sejenisnya. Dari seluruh negara-negara anggota ASEAN, Indonesia merupakan negara pertama yang mengimplementasikan Pajak Pertambahan Nilai, kemudian baru diikuti oleh beberapa negara lainnya. Ada negara anggota ASEAN yang menggunakan pajak lain, dan bukan Pajak Pertambahan Nilai. Tulisan ini akan melakukan suatu perbandingan mengenai penerapan Pajak Pertambahan Nilai atau pajak sejenis di beberapa negara anggota ASEAN. Studi perbandingan ini diharapkan akan dapat membantu dalam memberikan suatu gambaran mengenai penerapan Pajak Pertambahan Nilai atau sejenisnya di negara-negara anggota ASEAN, dan 
diharapkan pula akan dapat membantu dalam proses melakukan integrasi ekonomi melalui Masyarakat Ekonomi ASEAN, khususnya berhubungan dengan Pajak Pertambahan Nilai atau sejenisnya.

\section{PAJAK LANGSUNG DAN TIDAK LANGSUNG}

Pajak langsung adalah suatu iuran kepada pemerintah yang dapat dipaksakan, dan harus dibayar oleh orang pribadi, atau badan secara langsung kepada pemerintah. Pajak langsung tidak dapat dipindahkan kewajibannya untuk membayar kepada pihak lain. Contoh pajak yang tergolong pajak langsung adalah Pajak Penghasilan, dan jenis pajak lain yang berhubungan dengan penghasilan, dan kekayaan dari wajib pajak. Sedangkan pajak tidak langsung adalah pajak yang dipungut oleh pihak lain dari pihak yang wajib membayarkan. Pajak tidak langsung dapat dialihkan kewajibannya kepada pihak lain. Contoh dari pajak tidak langsung adalah jenis pajak konsumsi.

Pajak langsung yang dikenal secara umum dan biasanya menjadi salah satu pemasukan utama dari penerimaan pajak suatu negara adalah Pajak Penghasilan. Beberapa negara ada yang membedakan Pajak Penghasilan menjadi Pajak Penghasilan Orang Pribadi/Individu dan Pajak Penghasilan untuk Korporasi/ Badan. Tapi negara-negara yang lain tidak melakukan pemisahan secara konkrit, tetap menggunakan nama Pajak Penghasilan dengan pengaturan meliputi pemajakan atas orang pribadi dan badan.

Pajak tidak langsung yang banyak dikenal adalah Pajak Penjualan, Pajak atas Jasa, Pajak Ritel, dan Pajak Pertambahan Nilai. Dari semua jenis pajak tidak langsung ini yang terbanyak digunakan adalah Pajak Pertambahan Nilai. Walaupun demikian, masih ada beberapa negara yang masih menggunakan jenis pajak lainnya. Pajak Pertambahan Nilai walaupun merupakan jenis pajak multi stage, namun bersifat non cumulative sehingga seharusnya tidak memberatkan, karena tidak mengenakan pajak yang berganda atas objek yang sama. Pajak Pertambahan Nilai hanya dikenakan atas nilai tambahnya saja, bukan nilai barang dan jasa secara keseluruhan.

Di tingkat global, dari seluruh pendapatan dunia pada tahun 2018, sebesar $34,01 \%$ berasal dari penerimaan pajak atas barang dan jasa yang merupakan pajak tidak langsung (World Bank-a, 2019). Sedangkan pajak atas penghasilan, laba, dan keuntungan dari modal yang merupakan pajak langsung hanya memberikan kontribusi sebesar 24,56\% dari seluruh pendapatan dunia (World Bank-c, 2019).

\section{PAJAK PERTAMBAHAN NILAI}

Pajak Pertambahan Nilai pertama kali dimulai dengan beberapa perintis pada 1960-an, dan saat ini Pajak Pertambahan Nilai mulai menyebar di seluruh dunia (Vazquez and Bird, 2010). Pajak Pertambahan Nilai telah menjadi salah satu instrumen penting untuk mobilisasi pendapatan di negara berkembang. Saat ini, Pajak Pertambahan Nilai (PPN) ada di lebih dari 160 negara, termasuk di banyak negara berkembang yang telah memodernisasi sistem pajak mereka dalam beberapa dekade terakhir (Gerard and Naritomi, 2018).

Mengapa banyak negara di dunia akhirnya mengalihkan pajak konsumsinya dari Pajak Penjualan atau Pajak Retail menjadi Pajak Pertambahan Nilai? Menurut 
Tait (1988), negara menggunakan Pajak Pertambahan Nilai karena tidak puas dengan struktur pajak yang sudah ada. Penyebab ketidakpuasan mungkin salah satu atau semua dari 4 hal ini: (1) Pajak Penjualan yang ada tidak memuaskan, (2) adanya tuntutan pajak lintas negara yang diskriminatif dihapuskan; (3) pengurangan pajak lainnya; atau (4) evolusi sistem perpajakan belum sejalan dengan perkembangan ekonomi. Jadi ada beberapa faktor yang menyebabkan sebagian besar negara menggunakan Pajak Pertambahan Nilai menggantikan Pajak Penjualan, Pajak atas Jasa, Pajak Retail, atau jenis pajak konsumsi lainnya. Namun faktor yang utama dan pertama adalah karena jenis pajak konsumsi yang digunakan sebelumnya tidak memuaskan, sehingga perlu mencari alternatif pajak konsumsi yang tepat. Dalam hal ini, Pajak Pertambahan Nilai telah berhasil mengambil posisi sebagai pajak konsumsi yang paling tepat, dengan segala kelebihan yang dimiliki dibandingkan dengan pajak konsumsi lainnya. Walaupun ada kelemahan yang dimiliki, tetapi relatif kelebihan yang dimiliki jauh lebih banyak dibandingkan kekurangannya.

Pada prinsipnya, Pajak Pertambahan Nilai memiliki beberapa keunggulan dibandingkan dengan instrumen pajak lain yang lazim di negara-negara berkembang, yang menyebabkannya diterapkan secara luas di seluruh dunia (Gerard and Naritomi, 2018). Dengan penerapan Pajak Pertambahan Nilai ada beberapa sumber potensial peningkatan efisiensi. Dalam praktiknya, Pajak Pertambahan Nilai sering menggantikan Turnover Tax (yang dikenakan pada semua transaksi) atau Pajak Penjualan yang single stage (dikenakan pada tingkat ritel atau tingkat lainnya) (Keen and Lockwood, 2007).

Pajak Pertambahan Nilai seperti namanya hanya mengenakan pajak atas tambahan nilai yang terjadi dalam suatu rantai produksi dan distribusi. Orang pribadi, atau badan yang mempunyai jumlah penyerahan barang, dan atau jasa melebihi jumlah tertentu wajib memungut Pajak Pertambahan Nilai, dan disebut sebagai Pengusaha Kena Pajak (PKP). Jumlah tertentu tersebut yang dinamakan sebagai nilai ambang batas (Value Added Tax threshold).

Untuk menghitung Pajak Pertambahan Nilai yang terutang ada 3 metode yang dapat digunakan, yaitu: (i) invoice credit method; (ii) substraction method; dan (iii) addition method (Ebrill et al., 2001). Pada invoice credit method, setiap Pengusaha Kena Pajak yang menyerahkan barang, dan atau jasa harus memungut Pajak Pertambahan Nilai dan dinamakan Pajak Pertambahan Nilai Keluaran (selanjutnya akan disebut PPN Keluaran). Sedangkan pada waktu Pengusaha Kena Pajak membeli barang dan atau jasa yang dijualnya tersebut, dia harus membayar Pajak Pertambahan Nilai yang dinamakan sebagai Pajak Pertambahan Nilai Masukan (selanjutnya akan disebut PPN Masukan). Pada saat Pengusaha Kena Pajak membayar PPN Masukan, dia akan menerima dokumen yang dinamakan faktur pajak masukan. Demikian pula pada saat memungut PPN Keluaran, dia harus menerbitkan dokumen faktur pajak keluaran. Setiap periode tertentu biasanya 1 bulan, Pengusaha Kena Pajak harus melaporkan kepada otoritas pajak di negara Pengusaha Kena Pajak bertempat kedudukan atau bertempat tinggal mengenai jumlah PPN Keluaran yang dipungutnya dan jumlah PPN Masukan yang telah dibayarnya. Jika jumlah PPN Keluaran dari Pengusaha Kena Pajak tersebut lebih besar dari pada jumlah PPN Masukannya, maka 
Pengusaha Kena Pajak harus membayar selisih antara jumlah PPN Keluaran dengan PPN Masukan sebelum dia melaporkannya. Sebaliknya, bila jumlah PPN Keluaran dari Pengusaha Kena Pajak tersebut lebih kecil dari pada jumlah PPN Masukannya, maka Pengusaha Kena Pajak dapat meminta kembali (restitusi/refund) kelebihan pembayaran Pajak Pertambahan Nilai, senilai kelebihan jumlah PPN Masukan di atas jumlah PPN Keluaran. PPN Masukan yang dikurangkan dari PPN Keluaran, dinamakan PPN Masukan dikreditkan dengan PPN Keluaran. Setiap proses pengkreditan PPN Masukan harus dibuktikan dengan faktur pajak masukan. Oleh karena itu, metode ini dinamakan invoice credit method.

Pada substraction method, Pajak Pertambahan Nilai yang terutang langsung dihitung dari selisih antara harga jual dan harga beli dikalikan dengan tarif Pajak Pertambahan Nilai. Metode ini kelihatannya sederhana, namun apabila ingin diimplementasikan akan banyak kesukaran yang dihadapi. Hal ini dikarenakan suatu barang dan jasa yang dibeli belum tentu bisa langsung dijual seketika itu juga. Bila jarak waktu antara transaksi pembelian dan penjualan cukup panjang, maka akan terdapat kesulitan untuk menghitung selisih antara harga jual dan harga beli, mengingat harga barang per satuan yang dibeli sering bermacammacam. Demikian pula dengan harga jual persatuan yang kemungkinan bervariasi pula. Dibutuhkan administrasi yang rumit, apalagi jika harga beli dan harga jual mempunyai variasi yang cukup besar.

Jika digunakan metode addition method, maka besarnya Pajak Pertambahan Nilai terutang akan dihitung dengan mengalikan tarif Pajak Pertambahan Nilai dengan suatu estimasi harga tambahan (nilai tambah) yang dianggap wajar. Kesulitan dari metode ini adalah menghitung berapa besarnya nilai tambah yang wajar tersebut. Apabila nilai tambah yang diestimasikan tersebut tidak tepat, maka perhitungan besarnya Pajak Pertambahan Nilai terutang menjadi bias, artinya dapat terlalu besar, tetapi dapat pula terlalu kecil.

Dari ketiga metode perhitungan Pajak Pertambahan nilai terutang tersebut yang paling banyak digunakan adalah invoice credit method. Metode ini kelihatannya membutuhkan sistem administrasi yang lebih panjang dan banyak dibandingkan dengan 2 metode yang lain, karena harus membuat faktur pajak serta Pajak Pertambahan Nilai baru dapat ditentukan setelah menjumlahkan seluruh PPN Keluaran dan PPN Masukan yang lengkap faktur pajaknya. Namun metode ini diyakini akan menghasilkan perhitungan Pajak Pertambahan Nilai terutang yang lebih akurat, lebih pasti, dan sistem kontrolnya lebih mudah. Apabila suatu sistem perpajakan tidak akurat dan diragukan kepastiannya, maka akan mudah terjadi kericuhan atau sengketa antara wajib pajak dan otoritas pajak. Hal ini akan membuat hubungan antara wajib pajak dengan otoritas pajak akan penuh ketegangan dan konflik, yang pada akhirnya akan menciptakan suatu situasi pemungutan pajak yang tidak kondusif. Dalam kondisi demikian, besar kemungkinan target penerimaan pajak tidak akan tercapai. Demikian pula jika sistem yang dibangun sulit untuk dikontrol, maka kemungkinan terjadinya kecurangan-kecurangan pajak akan banyak. Kembali akhirnya pada situasi ini target penerimaan pajak tidak akan tercapai. 
Mekanisme perhitungan Pajak Pertambahan Nilai terutang dengan invoice credit method dapat dijelaskan berikut ini. Misalkan PT A sebagai pabrikan menjual barang dengan harga jual Rp. 50.000.000,- kepada PT B selaku pedagang besar. Kemudian barang tersebut dijual oleh PT B dengan harga Rp. 60.000.000,kepada PT C selaku pengecer. Oleh PT C barang tersebut dijual dengan harga Rp. 80.000.000,- kepada D selaku konsumen akhir (yang mengonsumsi barang tersebut). Apabila untuk memghitung Pajak Pertambahan Nilai terutang digunakan invoice credit method dan besarnya tarif Pajak Pertambahan Nilai sebesar 15\%, maka PT A harus menerbitkan faktur pajak keluaran untuk PT B sebesar Rp. 7.500.000,- (15\% x Rp. 50.000.000,-). PT B akan menerima faktur pajak masukan dari PT A sebesar Rp. 7.500.000,- dan harus menerbitkan faktur pajak keluaran untuk PT C sebesar Rp. 9.000.000,- (15\% x Rp. 60.000.000,-). Kemudian PT C menerima faktur pajak masukan sebesar Rp. 9.000.000,- dari PT B, dan harus menerbitkan faktur pajak keluaran sebesar Rp. 12.000.000,- (15\% X Rp. 80.000.000,-) untuk D sebagai konsumen akhir. Dalam hal ini, PT A akan mempunyai Pajak Pertambahan Nilai terutang sebesar Rp. 7.500.000,- dikurangi dengan PPN Masukan yang diterimanya pada saat membeli bahan mentah, bahan penolong, dan lainnya yang dipakai untuk memproduksi barang yang dijualnya kepada PT B. Sedangkan PT B mempunyai Pajak Pertambahan Nilai terutang sebesar Rp. 1.500.000,- (Rp. 9.000.000,- - Rp. 7.500.000,-). Kemudian PT C akan mempunyai Pajak Pertambahan Nilai terutang sebesar Rp. 3.000.000,- (Rp. 12.000.000,- - Rp. 9.000.000,-).

Keberhasilan suatu negara dalam mengimplementasikan Pajak Pertambahan Nilai antara lain ditentukan dari ketepatan negara tersebut dalam menentukan tarif Pajak Pertambahan Nilai. Setiap negara dapat menggunakan 1 tarif pajak, atau lebih. Penggunaan 1 tarif pajak lebih sederhana dan mudah dalam implementasinya. Tabel 1 menunjukkan jumlah negara yang menggunakan 1 tarif Pajak Pertambahan Nilai atau lebih.

Tabel 1

Jumlah Tarif yang Digunakan

Negara yang Menerapkan PPN

\begin{tabular}{|c|c|c|}
\hline No. & $\begin{array}{c}\text { Jumlah Tarif } \\
\text { yang Digunakan }\end{array}$ & $\begin{array}{c}\text { Persentase Jumlah } \\
\text { Negara yang } \\
\text { Menggunakan }\end{array}$ \\
\hline 1. & 1 tarif & $53 \%$ \\
\hline 2. & 2 tarif & $23 \%$ \\
\hline 3. & 3 tarif & $13 \%$ \\
\hline 4. & 4 tarif & $9 \%$ \\
\hline 5. & 5 tarif & $0 \%$ \\
\hline 6. & 6 tarif & $1 \%$ \\
\hline
\end{tabular}

Sumber: Ebrill et al. (2001)

Besarnya tarif Pajak Pertambahan Nilai harus ditentukan dengan sangat hati-hati. Tarif yang ditentukan terlalu besar dapat sangat memberatkan bagi masyarakat dan mungkin akan banyak yang berusaha untuk menghindarkan untuk 
membayarnya. Sebaliknya jika tarif Pajak Pertambahan Nilai ditentukan terlalu rendah, akan memberikan konsekuensi kecilnya kontribusi Pajak Pertambahan Nilai dalam penerimaan negara. Tabel 2 menunjukkan besarnya tarif Pajak Pertambahan Nilai yang digunakan berdasarkan kelompok negara.

Tabel 2

Besarnya Tarif PPN yang Digunakan Berdasarkan Kelompok Negara

\begin{tabular}{|l|c|}
\hline \multicolumn{1}{|c|}{ Kelompok Negara } & $\begin{array}{c}\text { Besarnya Tarif PPN } \\
\text { yang Digunakan }\end{array}$ \\
\hline Emerging and Developing Europe & $20,3 \%$ \\
\hline Advanced Economies & $18,0 \%$ \\
\hline Commonwealth of Independent States & $17,6 \%$ \\
\hline World & $15,6 \%$ \\
\hline Sub Saharan Africa & $15,6 \%$ \\
\hline Latin America and Carribean & $14,8 \%$ \\
\hline Middle East and North Africa & $14,0 \%$ \\
\hline Emerging and Developing Asia & $10,2 \%$ \\
\hline
\end{tabular}

Sumber: IMF (2019)

\section{PAJAK PERTAMBAHAN NILAI DAN SEJENISNYA DI NEGARA- NEGARA ASEAN-9}

Negara yang menjadi anggota ASEAN sebenarnya ada 11 negara, yaitu: Brunei Darussalam, Filipina, Indonesia, Kamboja, Laos, Malaysia, Myanmar, Singapura, Thailand, Timor Leste, dan Vietnam. Namun dalam pembahasan di sini hanya dipakai 9 negara ASEAN atau ASEAN-9, yaitu: Filipina, Kamboja, Laos, Malaysia, Myanmar, Singapura, Thailand, Vietnam, dan Indonesia. Pemilihan 9 negara ini dengan pertimbangan kelengkapan data yang tersedia. Data mengenai besarnya persentase jumlah pendapatan pajak dari PDB untuk negaranegara ASEAN-9 tahun 2017-2018 seperti terlihat pada Tabel 3.

Tabel 3

Persentase Pendapatan Pajak dari PDB Negara-Negara ASEAN-9 (2017-2018)

\begin{tabular}{|l|c|c|c|c|}
\hline \multicolumn{1}{|c|}{ Nama Negara } & $\begin{array}{c}2017 \\
(\%)\end{array}$ & $\begin{array}{c}2018 \\
(\%)\end{array}$ & Rata-rata (\%) & Peringkat *) \\
\hline Filipina & 14,24 & 14,72 & 14,48 & 3 \\
\hline Indonesia & 9,88 & 10,23 & 10,06 & 6 \\
\hline Kamboja & 15,79 & 17,05 & 16,42 & 1 \\
\hline Laos & - & - & - & - \\
\hline Malaysia & 12,95 & 12,03 & 12,49 & 5 \\
\hline Myanmar & 6,02 & - & $\mathrm{N} / \mathrm{A}$ & - \\
\hline Singapura & 14,19 & 13,47 & 13,83 & 4 \\
\hline Thailand & 14,81 & 14,97 & 14,89 & 2 \\
\hline Vietnam & - & - & - & - \\
\hline Tertinggi & 15,79 & 17,05 & 16,42 & - \\
\hline Terendah & 6,02 & 10,23 & 10,06 & - \\
\hline Dunia & 14,69 & 14,98 & 14,84 & - \\
\hline
\end{tabular}

Sumber: World Bank-b (2019) Diolah 
*) Peringkat diambil dari persentase rata-rata, mulai dari persentase rata-rata paling besar dengan peringkat pertama dan seterusnya sampai persentase rata-rata yang terkecil.

Dari Tabel 3, nampak bahwa dari 9 negara ASEAN-9, hanya 6 negara yang mempunyai data lengkap persentase jumlah pendapatan pajak dari PDB negaranegara ASEAN-9 untuk tahun 2017-2018. Persentase rata-rata terbesar ada di negara Kamboja sebesar $16,42 \%$, terendah ada di negara Indonesia sebesar $10,06 \%$ dan rata-rata sebesar dunia 14,84\%. Kemudian besarnya persentase jumlah pendapatan pajak dari barang dan jasa terhadap seluruh pendapatan negara-negara ASEAN-9 tahun 2017-2018 seperti terlihat pada Tabel 4.

Tabel 4

Persentase Jumlah Pendapatan Pajak dari Barang, dan Jasa Terhadap Jumlah Pendapatan Negara-Negara ASEAN-9 Periode 2017-2018

\begin{tabular}{|l|c|c|c|c|}
\hline \multicolumn{1}{|c|}{ Nama Negara } & $\begin{array}{c}2017 \\
(\%)\end{array}$ & $\begin{array}{c}2018 \\
(\%)\end{array}$ & $\begin{array}{c}\text { Rata-rata } \\
(\%)\end{array}$ & $\begin{array}{c}\text { Peringkat } \\
*)\end{array}$ \\
\hline Filipina & 26,96 & 27,28 & 27,12 & 4 \\
\hline Indonesia & 38,11 & 35,90 & 37,01 & 3 \\
\hline Kamboja & 45,77 & 48,04 & 46,91 & 1 \\
\hline Laos & - & - & - & - \\
\hline Malaysia & 28,66 & 19,46 & 24,06 & 5 \\
\hline Myanmar & 19,65 & - & N/A & - \\
\hline Singapura & 19,78 & 21,09 & 20,44 & 6 \\
\hline Thailand & 43,30 & 42,45 & 42,88 & 2 \\
\hline Vietnam & - & - & - & - \\
\hline Tertinggi & 45,77 & 48,04 & 46,91 & - \\
\hline Terendah & 19,65 & 19,46 & 20,44 & - \\
\hline Dunia & 33,15 & 34,01 & 33,58 & - \\
\hline
\end{tabular}

Sumber: World Bank-a (2019) Diolah

*) Peringkat diambil dari persentase rata-rata, mulai dari persentase rata-rata paling besar dengan peringkat pertama dan seterusnya sampai persentase rata-rata yang terkecil.

Untuk besarnya persentase jumlah pendapatan pajak dari barang dan jasa terhadap seluruh pendapatan 6 negara dari 9 negara-negara ASEAN-9 tahun 20172018, persentase rata-rata terbesar ada di negara Kamboja sebesar 46,91\% dan terendah ada di negara Singapura sebesar 20,44\%. Pajak Pertambahan Nilai atau pajak sejenisnya yang diberlakukan di negara-negara ASEAN-9 akan dijelaskan berikut ini. Sumber data utama dalam menelusuri impementasi Pajak Pertambahan Nilai atau pajak sejenisnya di negara-negara ASEAN-9 adalah PWC (2019) dan EY (2019). 


\section{PAJAK PERTAMBAHAN NILAI DI FILIPINA}

Pajak Pertambahan Nilai di Filipina mulai diberlakukan sejak tanggal 1 Januari 1988 menggantikan Pajak Penjualan. Pokok-pokok aturan mengenai Pajak Pertambahan Nilai yang diimplementasikan adalah sebagai berikut:

1. Pajak Pertambahan Nilai dikenakan terhadap penyerahan barang dan jasa.

2. Ambang batas untuk menjadi Pengusaha Kena Pajak (VAT threshold) adalah penjualan per tahun lebih dari PHP 3.000.000.

3. Tarif Pajak Pertambahan Nilai yang dipakai adalah tarif tunggal sebesar $12 \%$ untuk barang dan jasa, termasuk transaksi impor barang dan jasa.

4. Untuk transaksi ekspor, baik untuk barang maupun jasa, akan dikenakan tarif Pajak Pertambahan Nilai sebesar 0\%.

5. Jika Pengusaha Kena Pajak menyerahkan barang dan atau jasa kepada pemerintah atau lembaga lain di bawah kendali pemerintah, maka Pajak Pertambahan Nilainya tidak dibayarkan penuh, tetapi akan ditahan sebesar $5 \%$ dari nilai barang dan atau jasa yang diserahkan.

6. Sistem yang digunakan untuk menghitung besarnya Pajak Pertambahan Nilai terutang adalah invoice credit system, dengan menggunakan mekanisme pengkreditan PPN Masukan terhadap PPN Keluaran.

7. Pajak Pertambahan Nilai yang dibayar oleh turis tidak dapat diminta kembali (direstitusi).

\section{PAJAK PERTAMBAHAN NILAI DI KAMBOJA}

Pajak Pertambahan Nilai mulai diberlakukan di Kamboja pada tanggal 1 Januari 1999. Pokok-pokok aturan mengenai Pajak Pertambahan Nilai yang diimplementasikan adalah sebagai berikut:

1. Pajak Pertambahan Nilai dikenakan terhadap penyerahan barang dan jasa.

2. Tidak ada ambang batas untuk menjadi Pengusaha Kena Pajak (VAT threshold) bagi perusahaan, cabang perusahaan asing, dan kantor perwakilan. Sedangkan untuk orang pribadi, ambang batas menjadi Pengusaha Kena Pajak (VAT threshold) adalah penjualan per tahun lebih dari 125.000.000 Riel untuk penyerahan barang, 60.000.000 Riel untuk penyerahan jasa, serta 30.000.000 Riel untuk kontrak dengan pemerintah.

3. Tarif Pajak Pertambahan Nilai yang dipakai adalah tarif tunggal sebesar $10 \%$ untuk barang dan jasa, termasuk transaksi impor barang. Sedangkan transaksi impor jasa bukan merupakan subjek Pajak Pertambahan Nilai.

4. Untuk transaksi ekspor, baik untuk barang maupun jasa, akan dikenakan tarif Pajak Pertambahan Nilai sebesar $0 \%$.

5. Sistem yang digunakan untuk menghitung besarnya Pajak Pertambahan Nilai terutang adalah invoice credit system, dengan menggunakan mekanisme pengkreditan PPN Masukan terhadap PPN Keluaran.

6. Pajak Pertambahan Nilai yang dibayar oleh turis tidak dapat diminta kembali (direstitusi). 


\section{PAJAK PERTAMBAHAN NILAI DI LAOS}

Pajak Pertambahan Nilai mulai diberlakukan di Laos pada tanggal 1 Januari 2010. Pokok-pokok aturan mengenai Pajak Pertambahan Nilai yang telah diimplementasikan adalah sebagai berikut:

1. Pajak Pertambahan Nilai dikenakan terhadap penyerahan barang dan jasa.

2. Tidak ada ambang batas untuk menjadi Pengusaha Kena Pajak (VAT threshold). Semua orang pribadi dan badan yang menyerahkan barang dan jasa yang tidak dikecualikan harus melakukan registrasi untuk menjadi Pengusaha Kena Pajak, kecuali untuk usaha kecil.

3. Tarif Pajak Pertambahan Nilai yang dipakai adalah tarif tunggal sebesar $10 \%$ untuk barang dan jasa, termasuk transaksi impor barang dan jasa.

4. Untuk transaksi ekspor, baik untuk barang maupun jasa, akan dikenakan tarif Pajak Pertambahan Nilai sebesar 0\%.

5. Sistem yang digunakan untuk menghitung besarnya Pajak Pertambahan Nilai terutang adalah invoice credit system, dengan menggunakan mekanisme pengkreditan PPN Masukan terhadap PPN Keluaran.

6. Pajak Pertambahan Nilai yang dibayar oleh turis dapat diminta kembali (direstitusi).

\section{PAJAK PENJUALAN DAN PAJAK JASA DI MALAYSIA}

Pajak tidak langsung di Malaysia tidak dipungut dengan menggunakan sistem Pajak Pertambahan Nilai. Pajak tidak langsung yang diberlakukan di Malaysia dinamakan Pajak Penjualan dan Pajak Jasa (Sales Tax and Service Tax). Pajak Penjualan dan Pajak Jasa merupakan jenis pajak single stage yang diberlakukan sejak tanggal 1 September 2018. Sedangkan Pajak Jasa untuk jasa impor baru diberlakukan sejak 1 Januari 2019. Pokok-pokok aturan mengenai Pajak Penjualan yang diimplementasikan adalah sebagai berikut:

1. Pajak Penjualan diatur menggunakan undang-undang berbeda dengan yang mengatur Pajak Jasa.

2. Pajak Penjualan dikenakan hanya 1 kali (single stage) pada saat pabrikan melakukan penyerahan/penjualan barang hasil produksinya atau saat dilakukan impor barang.

3. Ambang batas menjadi Wajib Pajak Penjualan (Sales Tax threshold) adalah penjualan per tahun lebih dari RM 500.000.

4. Tarif Pajak Penjualan yang dipakai adalah sebesar 5\% dan $10 \%$ atas penyerahan barang hasil produksi oleh pabrikan atau atas impor barang.

5. Untuk barang yang diekspor tidak dikenakan Pajak Penjualan, karena dikecualikan sebagai objek dari Pajak Penjualan.

6. Pajak Pertambahan Nilai yang dibayar oleh turis tidak dapat diminta kembali (direstitusi).

Pokok-pokok aturan mengenai Pajak Jasa yang diimplementasikan adalah sebagai berikut:

1. Pajak Jasa diatur dengan menggunakan undang-undang yang berbeda dengan undang-undang yang mengatur Pajak Penjualan.

2. Pajak Jasa dikenakan saat ada jasa yang diberikan dan harus dipungut oleh pihak yang memberikan jasa. 


\section{Impelementasi Pajak Pertambahan Nilai di Indonesia: Suatu Studi Perbandingan di Negara-JNegara ASEAN-9}

3. Ambang batas menjadi Wajib Pajak Jasa (Service Tax threshold) ada bermacam-macam tergantung pada jasa yang diberikan. Jasa yang diberikan dikelompokkan menjadi 9 kelompok dengan 2 variasi ambang batas yang ditentukan, yaitu jumlah penjualan jasa per tahun lebih dari RM 500.000 dan RM 1.500.000.

4. Tarif Pajak Jasa yang dipakai adalah tarif tunggal sebesar $6 \%$, termasuk transaksi impor. Untuk penggunaan kartu kredit, baik kartu utama maupun kartu tambahan, akan dikenakan Pajak Jasa sebesar RM 25 per tahun.

5. Untuk transaksi ekspor tidak akan dikenakan Pajak Jasa.

\section{PAJAK KOMERSIAL DI MYANMAR}

Myamar tidak memiliki sistem Pajak Pertambahan Nilai. Pajak konsumsi yang digunakan disebut sebagai Pajak Komersial dan mulai digunakan sejak tanggal 31 Maret 1990. Pokok-pokok aturan mengenai Pajak Komersial yang diimplementasikan adalah sebagai berikut:

1. Pajak Komersial dikenakan terhadap penyerahan barang dan jasa, termasuk impor barang dan jasa.

2. Ambang batas untuk menjadi Wajib Pajak Komersial (Commercial Tax threshold) adalah penjualan per tahun lebih dari MMK 50.000.000.

3. Secara umum, tarif Pajak Komersial yang dipakai adalah 5\%. Tarif khusus sebesar $1 \%$, dan 3\% diberlakukan untuk penjualan perhiasan dari emas dan penjualan gedung.

4. Untuk transaksi ekspor, baik untuk barang maupun jasa, akan dikenakan tarif Pajak Komersial sebesar 0\%, kecuali untuk ekspor listrik yang akan dikenakan tarif $8 \%$ dan ekspor minyak mentah dikenakan tarif $5 \%$.

5. Pajak Komersial yang sudah dibayar pada saat pembelian barang, bahan baku, bahan penolong, jasa, dan semacamnya terkait dengan barang dan atau jasa yang akan diproduksi dan atau dijual dapat dikreditkan dengan Pajak Komersial yang dipungut pada saat penjualan barang dan atau jasa. Sistem yang dipakai tidak berbeda dengan invoice credit system pada pengkreditan PPN Masukan terhadap PPN Keluaran di Pajak Pertambahan Nilai.

6. Pajak Komersial yang dibayar oleh turis tidak dapat diminta kembali (direstitusi).

\section{PAJAK ATAS BARANG DAN JASA DI SINGAPURA}

Pajak Pertambahan Nilai di Singapura diberi nama Pajak atas Barang dan Jasa (Goods and Services Tax/GST) yang mulai diberlakukan pada tanggal 1 April 1994. Pokok-pokok aturan mengenai Pajak atas Barang dan Jasa yang diimplementasikan adalah sebagai berikut:

1. Pajak atas Barang dan Jasa dikenakan terhadap penyerahan barang dan jasa.

2. Ada ambang batas untuk menjadi Pemungut Pajak atas Barang dan Jasa (GST threshold) yaitu jumlah penjualan per tahun lebih dari S\$1.000.000.

3. Tarif Pajak atas Barang dan Jasa yang dipakai adalah tarif tunggal sebesar 7\% untuk barang dan jasa, termasuk transaksi impor.

4. Untuk transaksi ekspor, baik untuk barang maupun jasa, akan dikenakan tarif Pajak atas Barang dan Jasa sebesar 0\%. 
5. Pajak Penjualan atas Barang dan Jasa yang sudah dibayar pada saat pembelian barang, bahan baku, bahan penolong, jasa, dan semacamnya terkait dengan barang dan atau jasa yang akan diproduksi dan atau dijual dapat dikreditkan dengan Pajak atas Barang dan Jasa yang dipungut pada saat penjualan barang dan atau jasa. Sistem yang dipakai untuk perhitungan Pajak atas Barang dan Jasa yang terutang tidak berbeda dengan invoice credit system pada pengkreditan PPN Masukan terhadap PPN Keluaran di Pajak Pertambahan Nilai.

6. Pajak atas Barang dan Jasa yang dibayar oleh turis dapat diminta kembali (direstitusi).

\section{PAJAK PERTAMBAHAN NILAI DI THAILAND}

Pajak Pertambahan Nilai di Thailand mulai diberlakukan sejak tanggal 1 Januari 1992. Pokok-pokok aturan mengenai Pajak Pertambahan Nilai yang diimplementasikan adalah sebagai berikut:

1. Pajak Pertambahan Nilai dikenakan terhadap penyerahan barang dan jasa.

2. Ambang batas untuk menjadi Pengusaha Kena Pajak (VAT threshold) adalah penjualan per tahun lebih dari 1.800.000 Baht.

3. Tarif Pajak Pertambahan Nilai yang dipakai adalah tarif tunggal sebesar $7 \%$ untuk barang dan jasa, termasuk transaksi impor barang.

4. Untuk transaksi ekspor, baik untuk barang maupun jasa, akan dikenakan tarif Pajak Pertambahan Nilai sebesar 0\%.

5. Sistem yang digunakan untuk menghitung besarnya Pajak Pertambahan Nilai terutang adalah invoice credit system, dengan menggunakan mekanisme pengkreditan PPN Masukan terhadap PPN Keluaran.

6. Pajak Pertambahan Nilai yang dibayar oleh turis dapat diminta kembali (direstitusi).

\section{PAJAK PERTAMBAHAN NILAI DI VIETNAM}

Pajak Pertambahan Nilai mulai diberlakukan di Vietnam sejak tanggal 1 Januari 1999. Pokok-pokok aturan mengenai Pajak Pertambahan Nilai yang diimplementasikan adalah sebagai berikut:

1. Pajak Pertambahan Nilai dikenakan terhadap penyerahan barang dan jasa.

2. Tidak ada ambang batas yang ditetapkan untuk menjadi Pengusaha Kena Pajak (VAT threshold). Semua orang pribadi dan badan yang memproduksi dan menjual barang dan jasa kena pajak di dalam negeri atau yang mengimpor barang dan jasa kena pajak dari luar negeri untuk dikonsumsi di dalam negari digolongkan sebagai Pengusaha Kena Pajak.

3. Tarif Pajak Pertambahan Nilai yang dipakai adalah tarif sebesar 5\% dan $10 \%$ untuk barang dan jasa, termasuk transaksi impor barang dan jasa.

4. Untuk transaksi ekspor, baik untuk barang maupun jasa, akan dikenakan tarif Pajak Pertambahan Nilai sebesar 0\%.

5. Sistem yang digunakan untuk menghitung besarnya Pajak Pertambahan Nilai terutang adalah invoice credit system, dengan menggunakan mekanisme pengkreditan PPN Masukan terhadap PPN Keluaran. 
6. Pajak Pertambahan Nilai yang dibayar oleh turis dapat diminta kembali (direstitusi).

\section{PAJAK PERTAMBAHAN NILAI DI INDONESIA}

Pajak Pertambahan Nilai di Indonesia diatur dengan Undang-Undang Nomor 8 Tahun 1983 tentang Pajak Pertambahan Nilai dan Pajak Penjualan atas Barang Mewah sebagaimana telah beberapa kali diubah, terakhir dengan UndangUndang Nomor 42 Tahun 2009. Pajak Pertambahan Nilai di Indonesia mulai dimplementasikan pada tanggal 1 April 1985 berdasarkan Peraturan Pemerintah Nomor 22 Tahun 1985 tentang Pelaksanaan Undang-Undang Pajak Pertambahan Nilai 1984. Pokok-pokok aturan mengenai Pajak Pertambahan Nilai yang diimplementasikan adalah sebagai berikut:

1. Pajak Pertambahan Nilai dikenakan terhadap penyerahan barang dan jasa.

2. Ambang batas untuk menjadi Pengusaha Kena Pajak (VAT threshold) adalah penjualan per tahun lebih dari Rp. 4.800.000.000,-.

3. Tarif Pajak Pertambahan Nilai yang dipakai adalah tarif tunggal sebesar $10 \%$ untuk barang dan jasa, termasuk transaksi impor barang dan jasa.

4. Untuk transaksi ekspor, baik untuk barang maupun jasa, akan dikenakan tarif Pajak Pertambahan Nilai sebesar $0 \%$.

5. Bendaharawan Pemerintah dan badan-badan usaha tertentu dapat melakukan pemungutan Pajak Pertambahan Nilai.

6. Sistem yang digunakan untuk menghitung besarnya Pajak Pertambahan Nilai terutang adalah invoice credit system, dengan menggunakan mekanisme pengkreditan PPN Masukan terhadap PPN Keluaran.

7. Pajak Pertambahan Nilai yang dibayar oleh turis dapat diminta kembali (direstitusi).

\section{PERBANDINGAN PENERAPAN PAJAK PERTAMBAHAN NILAI DAN SEJENISNYA DI NEGARA-NEGARA ASEAN-9}

Negara-negara ASEAN-9 yang menggunakan Pajak Pertambahan Nilai dan yang tidak menggunakan terlihat seperti Tabel 5.

Tabel 5

Negara-Negara ASEAN-9 yang Menggunakan, dan Tidak Menggunakan Pajak Pertambahan Nilai

\begin{tabular}{|l|c|}
\hline \multicolumn{1}{|c|}{ Nama Negara } & $\begin{array}{c}\text { Menggunakan Pajak } \\
\text { Pertambahan Nilai }\end{array}$ \\
\hline Filipina & Ya \\
\hline Indonesia & Ya \\
\hline Kamboja & Ya \\
\hline Laos & Ya \\
\hline Malaysia & Tidak \\
\hline Myanmar & Tidak \\
\hline Singapura & Ya \\
\hline Thailand & Ya \\
\hline Vietnam & Ya \\
\hline
\end{tabular}


Dari 9 negara ASEAN-9 sebanyak 7 negara (77,78\%) menggunakan sistem Pajak Pertambahan Nilai dan 2 negara $(22,22 \%)$ tidak menggunakan sistem Pajak Pertambahan Nilai. Kedua negara yang tidak menggunakan sistem Pajak Pertambahan Nilai adalah Malaysia dan Myanmar. Negara yang pertama kali menggunakan sistem Pajak Pertambahan Nilai di negara-negara ASEAN-9 adalah Indonesia yang mulai mengimplementasikannya pada tanggal 1 April 1985. Dalam hal ini Indonesia telah mengambil posisi yang tepat dari awal dengan mengimplementasikan sistem Pajak Pertambahan Nilai untuk pemungutan pajak tidak langsungnya, sama dengan lebih dari 160 negara lainnya yang telah menerapkan sistem ini.

Mengenai ambang batas (threshold) sebagai pemungut Pajak Pertambahan Nilai, atau sejenisnya, 7 dari 9 negara-negara ASEAN-9 menggunakannya, sedangkan 2 negara lainnya, yaitu Laos dan Vietnam tidak menggunakannya. Besarnya ambang batas (threshold) yang digunakan negara-negara ASEAN-9 terlihat seperti Tabel 6. Untuk memudahkan memberikan perbandingan semua nilai ambang batas dijadikan rupiah.

Tabel 6

Besarnya Threshold yang Digunakan di Negara-Negara ASEAN-9 yang Menggunakan, dan Tidak Menggunakan Pajak Pertambahan Nilai

\begin{tabular}{|l|c|}
\hline \multicolumn{1}{|c|}{ Nama Negara } & $\begin{array}{c}\text { Besarnya Threshold } \\
\left.(\text { Rp. })^{*}\right)\end{array}$ \\
\hline Filipina & 823.035 .000 \\
\hline Indonesia & 4.800 .000 .000 \\
\hline Kamboja & 102.117 .000 \\
& 204.234 .000 \\
& 425.487 .500 \\
\hline Laos & - \\
\hline Malaysia & 1.698 .357 .500 \\
& 5.095 .072 .500 \\
\hline Myanmar & 469.875 .000 \\
\hline Singapura & 10.320 .740 .000 \\
\hline Thailand & 838.953 .000 \\
\hline Vietnam & - \\
\hline
\end{tabular}

*) Untuk Filipina, Malaysia, Singapura, dan Thailand konversi dari mata uang masing-masing negara ke rupiah menggunakan kurs tengah Bank Indonesia per 31 Desember 2019. Sedangkan untuk Kamboja dan Myanmar menggunakan kurs yang diambil dari https://id.Exchan ge-rates.org/Rate/KHR/IDR/2019-1231, dan https://id.exchange-rates .org/Rate/ MMK/IDR/2019-12-31.

Dari 7 negara ASEAN-9 yang menggunakan ambang batas (threshold), ada 5 negara yang menggunakan sistem Pajak Pertambahan Nilai dan 2 negara yang tidak menggunakan sistem Pajak Pertambahan Nilai. Ambang batas (threshold) ini harus ditetapkan dengan penuh kehati-hatian. Hal ini dikarenakan besarnya ambang batas akan mempengaruhi besarnya pendapatan yang diperoleh dari Pajak 
Pertambahan Nilai atau pajak sejenisnya. Umumnya semakin kecil ambang batas (threshold) yang ditetapkan, akan semakin besar pendapatan Pajak Pertambahan Nilai atau pajak sejenisnya yang bisa dihasilkan. Demikian pula semakin tinggi ambang batas (threshold) yang ditetapkan, seharusnya semakin kecil pendapatan Pajak Pertambahan Nilai atau pajak sejenisnya yang bisa dihasilkan.

Ambang batas (threshold) tertinggi ditetapkan Singapura dan ambang batas (threshold) terendah digunakan oleh Kamboja. Indonesia berada pada posisi ketiga, di bawah Singapura dan Malaysia dalam penentuan ambang batas (threshold). Kamboja yang menggunakan ambang batas (threshold) yang paling rendah, memiliki rata-rata persentase jumlah pendapatan Pajak dari Barang dan Jasa terhadap jumlah pendapatan yang terbesar dari 6 negara ASEAN-9 periode 2017-2018. Singapura yang menetapkan ambang batas (threshold) yang paling besar, memiliki rata-rata persentase jumlah pendapatan Pajak dari Barang dan Jasa terhadap jumlah pendapatan yang terkecil dari 6 negara ASEAN-9 periode 20172018. Sedangkan Indonesia telah menetapkan ambang batas (threshold) tertinggi ketiga dan memiliki rata-rata persentase jumlah pendapatan Pajak dari Barang dan Jasa terhadap jumlah pendapatan yang terbesar ketiga di antara 6 negara ASEAN9 periode $2017-2018$.

Untuk tarif Pajak Pertambahan Nilai atau pajak sejenisnya yang digunakan oleh negara ASEAN-9 (hanya tarif standar) dapat terlihat pada Tabel 7 berikut ini.

Tabel 7

Besarnya Tarif Pajak yang Digunakan di Negara-Negara ASEAN-9 yang Menggunakan dan Tidak Menggunakan Pajak Pertambahan Nilai

\begin{tabular}{|l|c|}
\hline \multicolumn{1}{|c|}{ Nama Negara } & Tarif Pajak \\
\hline Filipina & $12 \%$ \\
\hline Indonesia & $10 \%$ \\
\hline Kamboja & $10 \%$ \\
\hline Laos & $10 \%$ \\
\hline Malaysia & $\begin{array}{c}10 \% \text { (barang), dan } \\
6 \%(j a s a)\end{array}$ \\
\hline Myanmar & $5 \%$ \\
\hline Singapura & $7 \%$ \\
\hline Thailand & $7 \%$ \\
\hline Vietnam & $10 \%$ \\
\hline Rata-rata $*$ ) & $9 \%$ \\
\hline
\end{tabular}

*) Rata-rata dengan tidak memasukkan tarif jasa di Malaysia

Ditinjau dari tarif standar, yang tertinggi adalah Filipina dengan tarif sebesar $12 \%$. Kemudian disusul oleh Indonesia, Kamboja, Laos, Malaysia (barang), dan Vietnam dengan tarif sebesar $10 \%$. Yang menggunakan tarif standar di bawah $10 \%$ adalah Singapura dan Thailand dengan tarif sebesar 7\%, Malaysia untuk jasa dengan tarif sebesar 6\%, dan Myanmar dengan tarif sebesar 5\%. Jika dibandingkan dengan negara-negara ASEAN-9 lainnya, Indonesia memiliki tarif nomor 2 tertinggi bersama-sama dengan Kamboja, Laos, Malaysia, dan Vietnam. 
Tetapi masih di atas 3 negara yaitu Singapura, Thailand, dan Myanmar. Tarif yang digunakan Indonesia juga masih lebih tinggi dari rata-rata tarif negaranegara ASEAN-9 yang hanya 9\%. Jika dibandingkan dengan rata-rata tarif negara-negara berkembang di Kawasan Asia sebesar 10,2\%, tarif sebesar 10\% yang diterapkan Indonesia sudah mendekati.

Semua negara-negara ASEAN-9 menerapkan tarif 0\% untuk ekspor, kecuali Myanmar yang menerapkan tarif sebesar 8\%, dan 5\%, masing-masing untuk ekspor listrik dan minyak mentah. Di samping itu semua negara-negara ASEAN-9 menerapkan pajak yang dibayar pada waktu melakukan pembelian guna kepentingan produksi dan distribusi barang dan jasa yang akan dijual bisa dikreditkan dengan pajak yang dipungut pada waktu dilakukan penjualan barang dan jasa tersebut, kecuali Malaysia yang menerapkan Pajak Penjualan dan Pajak Jasa yang single stage pada tingkat pabrikan. Penggunaan sistem Pajak Penjualan dan Pajak Jasa yang diterapkan seperti ini akan merugikan pendapatan negara yang bersangkutan. Karena yang dipungut hanya pajak atas nilai jual dari pabrikan, sedangkan nilai tambah yang timbul sampai dengan ke konsumen akhir tidak dikenakan pajak. Hampir semua negara memberikan restitusi Pajak Pertambahan Nilai atau pajak sejenisnya untuk turis, kecuali Kamboja dan Myanmar yang tidak memberikan restitusi.

Secara keseluruhan, impelementasi Pajak Pertambahan Nilai di Indonesia sudah sangat baik dan moderat. Sebagai negara pelopor yang menggunakan sistem Pajak Pertambahan Nilai di negara-negara ASEAN-9, Indonesia telah menunjukkan bahwa administrasi Pajak Pertambahan Nilai yang dimplementasikannya dengan berbasis pada invoice credit method sudah sangat baik. Ambang batas (VAT threshold) yang ditetapkan sudah cukup tepat, tidak terlalu besar dan tidak terlalu kecil. Hal ini nampak ketika dibandingkan dengan negara-negara ASEAN-9 lainnya, Indonesia berada pada posisi di tengah, dengan nilai yang tidak terlalu rendah atau terlalu tinggi.

Keputusan Indonesia dengan hanya menggunakan 1 tarif Pajak Pertambahan Nilai sudah sangat tepat, karena akan memudahkan Pengusaha Kena Pajak dalam mengimplementasikannya dibandingkan dengan penggunaan beberapa macam tarif yang berbeda. Besarnya tarif yang diterapkan sebesar $10 \%$ juga sudah cukup tepat. Karena tarif 10\% ini juga digunakan mayoritas negara-negara ASEAN-9. Jika dibandingkan dengan rata-rata tarif negara-negara berkem-bang di kawasan Asia sebesar 10,2\%, tarif yang digunakan Indonesia ini sudah hampir sama.

Walaupun hampir semua aspek dari implementasi Pajak Pertambahan Nilai di Indonesia sudah sangat baik, terutama jika dibandingkan dengan negara-negara ASEAN-9, tetapi ada beberapa hal yang perlu dipertimbangkan untuk disempurnakan. Hal pertama terkait dengan pemungutan Pajak Pertambahan Nilai oleh Bendaharawan Pemerintah dan badan-badan usaha tertentu, pada saat Bendaharawan Pemerintah dan badan-badan usaha tertentu tersebut membeli barang dan atau jasa dari Pengusaha Kena Pajak. Dengan adanya pemungutan ini, maka Pengusaha Kena Pajak pasti akan mengalami kelebihan bayar Pajak Pertambahan Nilai pada saat mengkreditkan PPN Masukan terhadap PPN Keluaran. Hal ini akan berulang terjadi terus sepanjang tahun pajak, jika Pengusaha Kena Pajak menjual barang dan jasa kepada Bendaharawan 
Pemerintah dan badan-badan usaha tertentu tersebut. Untuk menyelesaikan hal tersebut, Pengusaha Kena Pajak harus mengajukan restitusi pengembalian kelebihan pembayaran Pajak Per-tambahan Nilai tersebut. Dalam hal ini akan dibutuhkan banyak waktu bagi Pengusaha Kena Pajak untuk mendapatkan uang restitusi, di samping juga harus menyediakan waktu guna menyiapkan data bagi pemeriksa pajak yang akan memastikan kebenaran restitusi.

Pemungutan Pajak Pertambahan Nilai oleh Bendaharawan Pemerintah dan badan-badan usaha tertentu tersebut, pada saat mereka membeli barang dan atau jasa dari Pengusaha Kena Pajak tidak sesuai dengan prinsip dasar sistem Pajak Pertambahan Nilai, karena akan memotong mekanisme pengkreditan PPN Masukan dengan PPN Keluaran pada rantai produksi dan distribusi. Seharusnya mekanisme pengkreditan PPN Masukan dengan PPN Keluaran tersebut tidak boleh terputus. Dari negara-negara ASEAN-9, di luar Indonesia hanya Filipina yang mempunyai aturan semacam ini, namun jumlah yang dipungut juga relatif tidak terlalu besar, yaitu hanya 5\% dari 17\% Pajak Pertambahan Nilai yang harus dibayar. Oleh karena itu, Pemerintah Indonesia dalam hal ini perlu mempertimbangkan untuk menghapus mekanisme pemungutan Pajak Pertambahan Nilai oleh Bendaharawan Pemerintah dan badan-badan usaha tertentu.

Hal kedua yang perlu diperhatikan adalah mengenai persentase jumlah pendapatan pajak dari PDB Indonesia yang hanya sebesar $10,06 \%$ serta menempati peringkat yang terakhir dari 6 negara-negara ASEAN-9 pada periode 2017-2018. Perbedaannya cukup jauh dibandingkan dengan Kamboja yang menempati peringkat pertama dengan persentase rata-rata sebesar $16,42 \%$. Dibandingkan dengan persentase rata-rata dunia juga masih cukup jauh, di mana persentase rata-rata dunia sebesar $14,84 \%$. Oleh karena itu, Pemerintah Indonesia harus melakukan berbagai upaya secara intens untuk meningkatkan persentase ini.

Dari perbandingan secara menyeluruh untuk semua negara-negara ASEAN9, nampak bahwa Pajak Pertambahan Nilai atau pajak sejenisnya yang diimplementasikan di semua negara-negara ASEAN-9 tidak berbeda jauh. Yang menjadi objek pengenaan pajak hampir semuanya sama, yaitu penyerahan barang, dan jasa, termasuk impor. Mayoritas sudah menggunakan ambang batas (threshold), kecuali Laos dan Vietnam. Tarif yang digunakan juga tidak berbeda jauh, dengan mayoritas negara-negara ASEAN-9, yaitu berada di angka 10\%, dengan rata-rata $9 \%$. Hampir semua negara memperbolehkan pajak yang sudah dibayar pada waktu pembelian untuk dikurangkan/dikreditkan dari pajak yang dipungut pada waktu penjualan, kecuali Malaysia yang menggunakan pajak tipe single stage. Untuk transaksi ekspor semua negara mengenakan tarif $0 \%$, kecuali Myanmar yang mengenakan tarif sebesar 5\% untuk ekspor minyak mentah dan $8 \%$ untuk ekspor listrik. Dengan adanya banyak persamaan Pajak Pertambahan Nilai atau pajak sejenisnya yang diimplementasikan di negara-negara ASEAN-9, maka proses untuk melakukan harmonisasi Pajak Pertambahan Nilai atau pajak sejenisnya di negara-negara ASEAN-9 akan dapat dilaksanakan dengan lebih mudah. Kondisi yang ada ini dapat mendorong pemikiran untuk menyusun satu Pajak Pertambahan Nilai atau pajak sejenisnya yang diberlakukan untuk seluruh 
negara anggota komunitas ASEAN. Hal ini tentu akan dapat mendukung usahausaha percepatan integrasi ekonomi negara-negara komunitas ASEAN.

\section{SIMPULAN}

Negara-negara ASEAN-9 mayoritas, yaitu 7 negara telah menggunakan sistem Pajak Pertambahan Nilai dan 2 negara lainnya, yaitu Malaysia dan Myanmar masih menggunakan sistem pajak tidak langsung lainnya. Mayoritas negara-negara ASEAN-9, yaitu sebanyak 7 negara telah menggunakan ambang batas (threshold) dan 2 negara lain, yaitu Laos dan Vietnam tidak menggunakannya. Tarif Pajak Pertambahan Nilai atau pajak sejenisnya yang tertinggi adalah di Filipina sebesar 12\%, dan yang terendah adalah di Myanmar sebesar 5\%, dengan rata-rata sebesar 9\%. Semua negara-negara ASEAN-9 menerapkan tarif $0 \%$, atau mengecualikan pengenaan Pajak Pertambahan Nilai atau pajak sejenisnya terhadap transaksi ekspor, kecuali Myanmar yang mengenakan tarif sebesar 5\% untuk ekspor minyak mentah dan $8 \%$ untuk ekspor listrik.

Dari keseluruhan negara-negara ASEAN-9, implementasi Pajak Pertambahan Nilai di Indonesia masih yang terbaik. Secara umum sistem Pajak Pertambahan Nilai atau pajak sejenisnya yang diimplementasikan negara-negara ASEAN-9 mempunyai banyak kesamaan, sehingga jika diinginkan untuk menyusun satu sistem Pajak Pertambahan Nilai atau pajak sejenisnya yang diberlakukan untuk semua negara anggota komunitas ASEAN seharusnya dapat dengan mudah untuk terealisasi.

\section{SARAN}

Karena cenderung memutus mata rantai pengkreditan PPN Masukan terhadap PPN Keluaran, Indonesia sebaiknya menghapus aturan mengenai kewenangan Bendahawaran Pemerintah dan badan-badan usaha tertentu untuk memungut Pajak Pertambahan Nilai dari Pengusaha Kena Pajak. Di antara negara-negara anggota ASEAN-9, Indonesia mempunyai persentase penerimaan pajak dari PDB yang terendah. Oleh karena itu, berbagai usaha perlu dilakukan untuk meningkatkannya.

Dalam rangka mempercepat integrasi ekonomi komunitas ASEAN, maka perlu adanya keseragaman pengenaan pajak tidak langsung, yang bisa berbentuk Pajak Pertambahan Nilai atau pajak tidak langsung lainnya. Usaha-usaha ke arah tersebut harus dilakukan secara lebih intensif dengan menyamakan persepsi dan meminimalkan perbedaan yang ada antar negara-negara anggota ASEAN.

\section{DAFTAR KEPUSTAKAAN}

Bank Indonesia, 2019, Kurs Transaksi Bank Indonesia, diakses dari https: //www.bi.go.id/id/moneter/informasi-kurs/transaksi-bi/Default.aspx.

Bird, Richard M., 2005, Value-Added Taxes in Developing and Transitional Countries: Lessons and Questions, ITP Paper 0505, International Tax Program Institute for International Business Joseph L. Rotman School of Management University of Toronto Toronto, Ontario Canada M5S 3E6. 
Charlet, Alain and Stéphane Buydens, 2012, The OECD International VAT/GST Guidelines: Past, and Future Developments, World Journal of VAT/GST Law, Vol. 1, Issue 2, pages 175-184.

Ebrill, Liam, Michael Keen, Jean-Paul Bodin, and Victoria Summers, 2001, The Modern VAT, International Monetary Fund, Washington, D.C..

EY, 2019, World Wide VAT, GST, and Sales Tax Guide 2019, EY Tax Global.

Gerard, Francois and Joana Naritomi, 2018, Value Added Tax in Developing Countries: Lessons from Recent Research, IGC Growth Brief Series 015, International Growth Centre, London.

https://id.Exchange-rates.org/Rate/KHR/IDR/2019-12-31, diakses 5 Januari 2020.

https://id.exchange-rates.org/Rate/MMK/IDR/2019-12-31, diakses 5 Januari 2020.

IMF, 2019, https://www. imf.org/exter nal/np/fad/tpaf/pages/vat.htm.

Keen, Michael and Ben Lockwood, 2007, The Value Added Tax: Its Causes, and Consequences, EUI Working Paper ECO 2007/09, Department of Economics, European University Institute.

OECD, 2019, Reveue Statistics 2019: Tax Revenue Trends in The OECD.

Peraturan Pemerintah Nomor 22 Ta-hun 1985 tentang Pelaksanaan UndangUndang Pajak Pertambahan Nilai 1984.

PWC, 2019, A Guide to VAT/GST in Asia Pacific 2019.

Tait, Alan A, 1988, Value Added Tax: International Practice, and Problems, International Monetary Fund, Washington, D.C..

Undang-Undang Nomor 8 Tahun 1983 tentang Pajak Pertambahan Nilai, dan Pajak Penjualan atas Barang Mewah sebagaimana telah beberapa kali diubah, terakhir dengan Undang-Undang Nomor 42 Tahun 2009.

Vazquez, Jorge Martinez and Richard M. Bird, 2010, Value Added Tax: Onward, and Upward, Working Paper 10-26, International Studies Program, Andrew Young School of Policy Studies, George State University, Atlanta, Georgia 30303, United States of America.

World Bank-a, 2019, https://data.worl dbank.org/indicator/GC.TAX.GSRV.RV. ZS.

World Bank-b, 2019, https://data.worl dbank.org/indicator/GC.TAX.TOTL. GD.ZS.

World Bank-c, 2019, https://data.worl dbank.org/indicator/GC.TAX.YPKG.CN. 